\title{
Handling and Curing Characteristics of Cut-Strip Tobacco. Part 1: Effect of Strip-Size, Packing Density and Mode of Orientation*
}

\author{
by \\ W.H. Johnson ${ }^{I}$, J.H. Young ${ }^{I}$, W.W. Weeks ${ }^{2}$, G.H. Ellington ${ }^{1}$, and J.C. Tutor ${ }^{2}$ \\ ${ }^{I}$ North Carolina State University, Department of Biological and Agricultural Engineering, U.S.A. \\ ${ }^{2}$ North Carolina State University, Department of Crop Science, U.S.A.
}

\section{SUMMARY}

Previous work has demonstrated potential handling and curing efficiencies in the use of cut-strip tobacco. The present work considers further the effect of cut-strip size, packing density and mode of orientation on cured leaf chemistry (starch, reducing sugars, and total alkaloids) and leaf quality. Results showed that cured leaf chemistry of $15.2 \times 22.9 \mathrm{~cm}$ cut-strip more closely matched properties of whole leaf than pieces $15.2 \times 15.2 \mathrm{~cm}$ or smaller. Starch contents were significantly higher for the smaller cut-strip sizes, perhaps due to edge drying effects, while alkaloids were significantly lower. Within the range of 194 to 292 $\mathrm{kg} / \mathrm{m}^{3}$, packing density had little effect on leaf chemistry, with the exception that reducing sugars were slightly lower for the higher packing densities. This could be due to a longer time for the drying front to move through the more tightly packed tobacco, and hence more respiratory loss of sugars. Government grades and average market prices of cured strips were essentially unaffected over the range of strip sizes or packing densities tested. Based on airflow resistance measurements and observed drying characteristics, vertical orientation of strips was far superior to horizontal orientation, both with vertical airflow through the tobacco. The higher packing density reduced specific energy use $(\mathrm{kWh} / \mathrm{kg}$ green tobacco) by as much as $22 \%$, indicating potential energy savings for cut-strip over whole leaf curing. [Beitr. Tabakforsch. Int. 20 (2002) 7-13]

\section{ZUSAMMENFASSUNG}

Frühere Untersuchungen haben die Brauchbarkeit bestimmter Verfahren bei der Behandlung und Trocknung von in Streifen geschnittenem Tabak aufgezeigt. In der vorliegenden Arbeit wird die Auswirkung der Größe der Steifen, der Packungsdichte und die Art der Orientierung auf die chemischen Eigenschaften (Stärke, reduzierende Zucker und Gesamtalkaloide) und die Qualität der getrockneten Tabakblätter näher untersucht. Die Ergebnisse haben gezeigt, dass die chemischen Eigenschaften von $15.2 \times$ $22.9 \mathrm{~cm}$ großen Strips eher den Eigenschaften ganzer Blätter entsprechen als Blattteile von $15.2 \times 15.2 \mathrm{~cm}$ Größe oder kleiner. Der Stärkegehalt war bei den kleineren Streifen signifikant höher, möglicherweise wegen des Effekts der Trocknung an den Rändern, während der Alkaloidgehalt signifikant niedriger war. In einem Bereich zwischen 194 bis $292 \mathrm{~kg} / \mathrm{m}^{3}$ hatte die Packungsdichte wenig Auswirkung auf die Blattchemie mit der Ausnahme, dass reduzierende Zucker bei höherer Packungsdichte in etwas geringeren Konzentrationen vorlagen. Dies könnte darauf zurückzuführen sein, dass die Ausbreitung der Trocknungsgrenze bei dichter gepacktem Tabak länger dauert und es somit zu einem stärkeren oxidativen Abbau bei den Zuckern kommt. Die amtlich festgesetzten Grade und durchschnittlichen Marktpreise getrockneter Strips standen in der Regel mit der Größe der untersuchten Streifen oder den Packungsdichten nicht in Beziehung. Durch Luftstrom-Widerstandsmessungen und den festgestellten Trocknungscharakteristika ergab sich, bei in beiden Fällen vertikalem Luftstrom durch den Tabak, eine 
deutliche Überlegenheit der vertikalen Lage der Streifen im Vergleich zur horizontalen Orientierung. Die höhere Packungsdichte reduzierte den spezifischen Einsatz von Energie (kWh/kg frischen Tabaks) sogar um $22 \%$, was auf mögliche Energieeinsparungen bei der Trocknung von Strips im Vergleich zu ganzen Tabakblättern hindeutet. [Beitr. Tabakforsch. Int. 20 (2002) 7-13]

\section{RESUME}

Des travaux antérieurs ont démontré l'efficacité de la manipulation et du séchage dans l'utilisation du tabac découpé. Cette étude examine l'effet de la taille des strips de tabac, la densité d'emballage et le mode d'orientation sur la chimie des feuilles séchées (amidon, sucres réducteurs et alcaloïdes totaux), sur la qualité des feuilles. Les résultats montrent que la chimie des strips séchés d'une taille de $15.2 \times 22.9 \mathrm{~cm}$ correspond plus étroitement à celle des feuilles entières que la chimie des morceaux de feuilles de tabac d'une taille de $15.2 \times 15.2 \mathrm{~cm}$ ou encore plus petit. La teneur en amidon est significativement plus élevée dans les morceaux les plus petits, peut-être en raison de l'effet de séchage sur les bords, tandis que la teneur en alcaloïdes est significativement plus faible.

Avec une densité de 194 à $292 \mathrm{~kg} / \mathrm{m}^{3}$, la densité d'embal= lage a peu d'effet sur la chimie de la feuille, cependant la concentration en sucres réducteurs est plus faible dans les emballages plus denses. Ceci peut être dû au fait que le séchage dure plus longtemps pour les tabacs emballés plus fermement, et ainsi à une perte respiratoire accrue des sucres. Les grades officiels et les prix moyens du marché des strips séchés ne sont influencés par la gamme des diverses tailles de strips examinés ou les densités d'emballage testées. Basé sur la mesure de la résistance des flux d'air et l'analyse des caractéristiques de séchage, l'orienta= tion verticale des strips s'est montrée très supérieure par rapport à l'orientation horizontale, avec dans les deux cas un flux d'air vertical à travers le tabac. La plus grande densité d'emballage a réduit l'utilisation de l'énergie spécifique ( $\mathrm{kWh} / \mathrm{kg}$ de tabac frais) jusqu'à $22 \%$, ce qui indique un potentiel d'économie d'énergie pour le séchage du tabac découpé par rapport au séchage des feuilles entières. [Beitr. Tabakforsch. Int. 20 (2002) 7-13]

\section{INTRODUCTION}

During the last 30 years, tobacco mechanization in the USA, along with lease and transfer of quota, has led to a dramatic increase in average size of tobacco production operations. Eighty to 150 ha operations are now common, with some exceeding 250 ha. Such operations require handling of up to four million $\mathrm{kg} / \mathrm{year}$ of harvested material from harvesters into bulk barns. The relatively low productivity of mechanical harvesters and rising labor costs, coupled with substantially lower quotas in the late 1990s, have marked the need for more advanced and efficient harvesting, handling, and curing systems.

Since the development of bulk tobacco curing during the 1950s (1), several investigators have explored the potential for handling and curing tobacco in a shredded or cut-strip form as a means of increasing harvesting and curing efficiency.

In early laboratory studies JOHNSON et al. (2) showed that edge effects resulting from shredding green tobacco were negligible when the tobacco was yellowed in a low-drying environment of $96 \%$ relative humidity. At $82 \%$ relative humidity, however, drying along the cut edges prematurely arrested certain biochemical reactions. In follow-up work, tobacco shredded into $1.27-\mathrm{cm}$ strips and cured in bulk had lower contents of sugar and nicotine than intact leaf (1). While the cured shredded leaf appeared quite normal, smoking tests indicated that the material lacked flavor and had an acrid aroma.

More than a decade later, after bulk curing in racks had been successfully adopted throughout the U.S. flue-cured states, field research was re-initiated at the Oxford Tobacco Research Station, Oxford, NC to examine the potential for curing cut-strips in pieces larger than those examined during the 1950s. From 1970 to 1976, research emphasis was on the development and testing of harvesting and curing equipment which would permit high capacity handling of cut-strip or intact leaves into large curing containers $(3,4,5)$. In 1970/71, additional studies compared cured leaf properties of cut-strip $(3.81 \times 7.6 \mathrm{~cm}$ and $7.6 \times$ $7.6 \mathrm{~cm}$ ) with those of intact leaf, both cured in bulk containers with capacities of 75 to $250 \mathrm{~kg}$. Special cutting equipment was developed to provide two cutting actions: slicing by means of rotary discs spaced at $3.81 \mathrm{~cm}$ and cross cutting by a rotating cutter and bed knife. Intact tobacco leaves were conveyed through the cutting machine and processed into sized pieces with minimal evidence of bruising. Although the cured cut-strips had sugar concentrations of $85 \%$ to $90 \%$ that of whole leaf, their appearance and physical properties as reflected in grade analyses closely matched those of the control. By 1974 the system had been further developed to include cutters mounted on a mechanical harvester. In operation, the cut material was deposited into a dump bin on the harvester, thereby permitting rapid transfer to live-bed transport trailers. At the curing barn, the harvested material was moved rapidly onto a conveyor/distributor unit $(150 \mathrm{~kg} / \mathrm{min}$ or higher $)$ and then distributed into large containers holding up to $525 \mathrm{~kg}$. Filled containers were subsequently mechanically moved into position for curing.

The above studies demonstrated several potential advantages of cut-strip tobacco compared to intact leaves. The cut-strip material was more suitable for high capacity materials handling, provided more uniform filling and higher packing densities of large box containers, and cured faster and more uniformly (3). Potential advantages to the leaf processor were that $40 \%$ or more of the cured material was stem-free and a portion of this could be removed prior to threshing. Over several years of physical, chemical, and smoke evaluations, cut-strips were rated as suitable for use in cigarette manufacturing, but in some years they had lower sugar and nicotine contents than intact leaves.

Successful incorporation of cut-strip tobacco into a mechanized production system would likely require modified packaging technology, such as baling. Therefore, this research was discontinued after 1976 primarily because 
industry leaders decided to continue marketing flue-cured tobacco in burlap sheets and rejected baling as a new marketing practice. Furthermore, curing in large boxes was just being adopted at the farm level and few farmers would have considered changing over to cut-strip technology at that time.

In 1994 Dr. M.D. BoYETTE, Department of Biological and Agricultural Engineering Department at N.C. State University, renewed investigations on curing of cut-strip tobacco. Using cutting equipment developed in the 1970s, exploratory work focused on curing trials in which a small barn was top-loaded with cut-strip material without rotation of the material (6). Results were only partially successful (incomplete drying and low packing density), and it was concluded that tobacco could be cured more efficiently in boxes with vertical strip orientation and having more horizontal rod support for the tobacco. Research using a higher capacity cutter was continued in 1995 using small bulk barns for major tests and commercial barns for a late season comparative test. Results verified earlier observations regarding potential advantages of cut-strip, with a commercial barn test showing a 50\% increase in barn capacity for the cut material over intact leaf. However, the cut-strip contained slightly lower sugars and alkaloids and significantly higher starch content than intact leaf, which could be of concern to the industry.

The research reported herein represents a continuation in 1996 of this renewed effort, with further examination of various process variables on handling and curing characteristics of cut-strip tobacco. Several factors that could possibly inhibit starch-to-sugar conversion or enhance respiration rate include: a) size of the cut-strip pieces (more rapid drying along cut edges); b) relative humidity of the curing environment during yellowing (higher humidity may reduce drying along the cut edge [2]); c) packing density in the curing box (a higher density means a larger quantity of water to be removed, possibly extending the time for respiration [7]); d) bruising (cell damage occurring during cutting and handling could retard starch-to-sugar conversion with increased respiratory rate $[8,9,10])$; e) mode of orientation during curing (horizontal $v s$. vertical orientation of pieces could affect air velocity and, hence, drying characteristics and length of respiration [11,12]); and f) respiration rate (known to be higher for smaller than larger tobacco strips and for higher temperatures).

Specific objectives of this research investigation were as follows: 1) conduction of comparative studies of whole leaf $v s$. cut-strip tobacco with emphasis on strategies to control sugar and starch content; 2) evaluation of cut-strip piece size, packing density, and mode of orientation on the physical and chemical properties of the cured leaf; and 3) minimization of curing environment effects by the use of a computerized curing/data collection system.

\section{MATERIALS AND METHODS}

\section{Equipment development}

Four small curing barns at the Central Crops Research Station, Clayton, NC were modified and certain equipment items were developed to accommodate the study. The barns were completely instrumented for computer control of wet and dry bulb conditions, using technology previously described (13). The electric furnaces of each barn were automatically energized as necessary to maintain the scheduled inlet dry-bulb temperature. Similarly, the inlet wet-bulb temperature was maintained by controlling the inlet damper by means of a linear actuator under computer control. The barns were also equipped with improved curing boxes that reduced air by-pass, and with flexible wall sealing strips to minimize air by-pass along sides of the curing boxes. For vertical mode orientation, existing curing boxes of about $0.7-\mathrm{m}^{3}$ volume were used, with four boxes providing approximately $2.8 \mathrm{~m}^{3}$ of tobacco volume per barn. For horizontal mode orientation, two new boxes were built for one barn, with each box having a volume of about 1.4 $\mathrm{m}^{3}$. Four spray nozzles, controlled manually or by computer, were mounted beneath each furnace to provide $18.2 \mathrm{~L} / \mathrm{h}$ water atomization for conditioning the tobacco after curing. Sensors were installed to measure wet and dry bulb temperatures below and above the tobacco and static pressure across the tobacco. In addition to regulating the desired curing conditions in the four barns, the computer also recorded conditions to disk at 15-min intervals.

A new tobacco cutter was designed and developed which provided flexibility in obtaining the desired cut-strip sizes. In principle, the tobacco moved on a conveyor belt and was sliced into $15.2-\mathrm{cm}$ strips by two banks of disc cutters. The tobacco then moved through a cross-cutter having two blades that rotated and cut the strips into rectangular sections. Cut-strip sizes (theoretical) of $15.2 \times 7.6 \mathrm{~cm}, 15.2$ $\times 15.2 \mathrm{~cm}$, and $15.2 \times 22.9 \mathrm{~cm}$ were easily provided within minutes by changing the drive sprocket chain assembly. In order to provide uniform, mechanized distribution of tobacco into curing containers, a conveyor distributor previously used in a project on cut-strip curing in the early 1970s was renovated by installing new belting, hold-down rollers, and other parts. This equipment provided elevation of the tobacco and distribution into the container by means of an oscillating vane that moved back and forth over the container. Since the elevator width was less than the width of a curing box, it was still necessary to translate the box beneath the distributor vane to obtain even filling. Two tracks of roller conveyor were provided for this purpose. In order to move the filled containers, some holding $340 \mathrm{~kg}$ or more tobacco, a gantry with an electric chain hoist was renovated from a previous curing project and a loading ramp was developed which could be used for all barns. The gantry lifted the filled box, moved it to the loading ramp, and lowered the box onto a guide track from which the box was rolled into the curing barn onto mating floor rails.

\section{Procedures}

Approximately 1 ha of field tobacco (variety K 326) was produced at the Central Crops Research Station. Tobacco was planted on April 29 and May 3, 1996; and total nitrogen applied pre- and post-plant was $77 \mathrm{~kg} / \mathrm{ha}$. Normal cultural practices were followed and the tobacco was irrigated as necessary. Hand harvesting was used to collect 3 to 4 leaves per priming when the leaves were adjudged to be ripe. 
Curing experiments were conducted from July 25 to late September. Treatments tested included: 1) three cut-strip sizes of $15.2 \times 7.6 \mathrm{~cm}, 15.2 \times 15.2 \mathrm{~cm}$, and $15.2 \times 22.9 \mathrm{~cm}$ compared to whole leaf; 2) packing densities of 194, 243, and $292 \mathrm{~kg} / \mathrm{m}^{3}$; and 3) vertical vs. horizontal strip orientation, both with vertical airflow. Typical packing densities of intact leaves used by farmers with box barns are about $194 \mathrm{~kg} / \mathrm{m}^{3}$, although previous studies used substantially higher densities, primarily with cut-strip tobacco $(14,3,7)$. Three barns were used for vertical orientation, with each barn assigned a given density. Three box containers within each barn were filled with the three sizes of cut-strip material and the fourth with intact leaf. This provided the same curing environment for the cut-strip and intact material for a given packing density. The fourth barn was used to test horizontal orientation using $15.2 \times 7.6 \mathrm{~cm}$ and $15.2 \times 15.2-\mathrm{cm}$ cut-strip only, and for selected packing densities.

The general procedure for a given week of harvest was as follows. The tobacco was harvested and hauled by trailer to the curing barns, where it was pre-weighed prior to filling of containers. The three cut-strip sizes and whole leaf treatments were randomized for the test. Filling of barns for a given leaf-size treatment was in the order of low density, medium density, and high density, all vertical mode, then horizontal mode. Tobacco was placed on the cutter conveyor (for cut-strip treatments), cut into sized pieces, then elevated and distributed into the box containers to the specified density of packing. Intact leaf by-passed the cutter and moved directly onto the elevator/distributor. Some redistribution of tobacco was made by hand as necessary to obtain uniform filling, especially along sides and corners of the boxes. Green core samples for chemical analyses were taken at three locations (replications) after filling the boxes. Boxes were closed, rods inserted at specified locations (for vertical and horizontal mode orientations), and boxes lifted by gantry and moved onto a special plenum for pressure versus airflow measurements (concurrent study by ANDERSON et al. [11]). Then the boxes were moved into the curing barns. Foam rubber was used to seal any openings along the rear and front walls, or between boxes as considered necessary. After filling all four barns, the barns were closed and curing placed under computer control. Curing schedules could be modified during the cure by making changes in the curing program. Generally, curing was accomplished following typical schedules of $32.2^{\circ} \mathrm{C}$ dry bulb, $29.5-30.6{ }^{\circ} \mathrm{C}$ wet bulb for yellowing over a 48 - to 60 -h period; followed by gradual elevation of dry bulb temperature to $57{ }^{\circ} \mathrm{C}$ with lowered humidity during leaf drying; and with final stem drying at $74{ }^{\circ} \mathrm{C}$. A total curing time of 6 to $7 \mathrm{~d}$ was normally required. Following curing, the tobacco was conditioned either by computer or manual control of the spray nozzles. Conditioned tobacco was unloaded, weighed, and sampled for chemical analyses; then it was placed into plastic bags or burlap sheets for storage.

Four tests were completed prior to Hurricane Fran (Sept. 5, 1996), which interrupted and caused abortion of cure 5 and caused devastating effects on the remaining upper stalk leaf. The tobacco remaining on the stalk after the hurricane was harvested and cured as cure 6; however, cured leaf chemistry was not included in this experiment.

Whereas green leaf samples were evaluated only for starch content, cured leaf samples were evaluated for starch, reducing sugars, and total alkaloids. The Tobacco Chemistry Laboratory at North Carolina State University (NCSU) conducted all analyses. It should be noted that green leaf samples included both lamina and midrib, whereas cured leaf samples included lamina only. A United States Department of Agriculture (USDA) district grade supervisor assigned government grades to treatment lots.

\section{RESULTS}

\section{Equipment performance}

The cutter worked well with little evidence of excessive bruising due to the cutting action or mechanical handling. Other equipment including conveyor, distributor, loading equipment, and curing barns worked well. A few problems were experienced with the computer-control system, but these were quickly identified and resolved without serious consequences to the cures in progress. Curing schedules achieved were relatively close to those programmed into the computer, with normal variance of about 1 to $2{ }^{\circ} \mathrm{C}$ around set points due to heater on-off cycling and damper actuation.

\section{Chemical analyses}

Table 1 presents green and cured leaf starch contents, averaged over cures 1 through 4 . Table 2 shows percent reducing sugars and alkaloids for cured leaf samples. Green leaf starch contents were quite variable, ranging from $10 \%$ to $41 \%$ in the raw data prior to averaging. The overall average for green samples was about $22 \%$. The greatest variation from this mean was for the $15.2 \times 7.6 \mathrm{~cm}$ cut-strip that averaged $17.6 \%$, significantly lower than for the other strip sizes or intact leaf. Since samples were taken before curing, this was unexpected. It is possible that the core samples for the smaller size strip material contained a higher percentage of midrib, perhaps associated with the cutting process. This would have lowered the sample starch content since midrib has a lower starch content than lamina. Cured leaf starch contents, on the other hand, were significantly higher for the two smaller strip sizes, with whole leaf having the lowest level of starch, on average. Faster drying along the cut edge could be a possible factor, with more drying for the smaller cut-strip sizes. Also, more bruising along the leaf surface and cut edges for the smaller cut-strip sizes may be a factor. Packing density had no significant effect on starch content, even though the two higher density treatments required more drying time than the lowest density treatment.

From Table 2 it is apparent that no consistent trend was found for cured leaf sugar in relation to strip size. Total alkaloids, however, increased significantly as strip size increased, and the effect was consistent for each packing density. However, packing density did not affect total alkaloid concentrations. Also, as packing density increased, reducing sugars significantly decreased. This may be due 
Table 1. Percent starch content for green and cured leaf samples (values shown represent averages over three replications [sampling locations] per cured lot, further averaged over cures 1 through 4)

\begin{tabular}{|c|c|c|c|c|c|}
\hline \multirow{3}{*}{$\begin{array}{l}\text { Leaf } \\
\text { sample } \\
\text { source }\end{array}$} & \multirow{3}{*}{$\begin{array}{l}\text { Leaf size } \\
(\mathrm{cm} \times \mathrm{cm})\end{array}$} & \multicolumn{3}{|c|}{ Packing density $\left(\mathrm{kg} / \mathrm{m}^{3}\right)$} & \multirow[b]{3}{*}{ Mean $^{\mathrm{a}}$} \\
\hline & & 194 & 243 & 292 & \\
\hline & & \multicolumn{3}{|c|}{ Starch $(\%)$} & \\
\hline \multirow[t]{5}{*}{ Green } & $15.2 \times 7.6$ & 17.8 & 17.1 & 17.8 & $17.6 \mathrm{a}$ \\
\hline & $15.2 \times 15.2$ & 22.5 & 24.1 & 25.2 & $23.9 \mathrm{~b}$ \\
\hline & $15.2 \times 22.9$ & 23.8 & 26.4 & 20.7 & $23.6 \mathrm{~b}$ \\
\hline & Whole leaf & 23.9 & 23.3 & 22.0 & $23.1 \mathrm{~b}$ \\
\hline & Mean & 22.0 & 22.7 & 21.4 & 22.1 \\
\hline \multirow[t]{5}{*}{ Cured } & $15.2 \times 7.6$ & 8.0 & 9.0 & 9.4 & $8.8 \mathrm{a}$ \\
\hline & $15.2 \times 15.2$ & 8.8 & 9.0 & 8.1 & $8.7 \mathrm{a}$ \\
\hline & $15.2 \times 22.9$ & 6.1 & 7.1 & 6.5 & $6.6 \mathrm{~b}$ \\
\hline & Whole leaf & 6.0 & 6.1 & 5.1 & $5.7 \mathrm{~b}$ \\
\hline & Mean & 7.2 & 7.8 & 7.3 & 7.4 \\
\hline
\end{tabular}

${ }^{a}$ Within leaf size for green or cured samples, average values with the same letters $(a, b)$ were not significantly different according to an $F$-protected LSD test at $P=0.05$.

to the longer time (estimated 10 to $20 \mathrm{~h}$ ) for the drying front to move through the more tightly packed tobacco, and hence more respiratory loss of sugars. A previous study (7) showed a consistent increase in airflow rate through tobacco as the bulk density decreased with time due to drying. In this study, it can be inferred that higher airflow rates and faster drying would be expected for the lower packing densities.

\section{Price evaluations}

Following government grading of the cured tobacco, USDA average market prices were assigned to the respective grades. Table 3 shows the USDA price summary for cured cut-strip and whole leaf tobacco for cures 1 through 4. Within a given cure, the grades were very close or essentially the same among the various treatment lots. Neither strip size nor packing density significantly affected government grades of cured tobacco for a given cure.

\section{Observations of vertical vs. horizontal orientation}

As noted earlier, airflow measurements were made on each box of tobacco prior to curing. For the first cure and for horizontal-mode curing, one box was filled with $15.2 \times$ 7.6-cm cut-strip and a second box with $15.2 \times 15.2-\mathrm{cm}$, both packed at $243 \mathrm{~kg} / \mathrm{m}^{3}$. It was noted that the $15.2 \times$ $15.2-\mathrm{cm}$ material offered more resistance to airflow than the $15.2 \times 7.6-\mathrm{cm}$ tobacco, as might be expected. Comparison of flow rates of horizontally oriented tobacco with vertically oriented tobacco of the same strip size and packing density showed that the vertical orientation offered considerably less resistance to air flow than the horizontal orientation. For a given velocity, leaves oriented perpendicular to the airflow had a pressure gradient about 10 times greater than that of the leaves oriented parallel to the airflow (11). Prior studies (12) also indicated similar
Table 2. Percent reducing sugars and alkaloids for cured leaf samples (values shown represent averages over three replications [sampling locations] per cured lot, further averaged over cures 1 through 4)

\begin{tabular}{|c|c|c|c|c|c|}
\hline \multirow[b]{2}{*}{ Component } & \multirow{2}{*}{$\begin{array}{l}\text { Leaf size } \\
(\mathrm{cm} \times \mathrm{cm})\end{array}$} & \multicolumn{3}{|c|}{ Packing density $\left(\mathrm{kg} / \mathrm{m}^{3}\right)$} & \multirow[b]{2}{*}{ Mean $^{\mathrm{a}}$} \\
\hline & & 194 & 243 & 292 & \\
\hline \multirow[t]{5}{*}{$\%$ Reducing sugars } & $15.2 \times 7.6$ & 13.3 & 12.9 & 12.6 & 12.9 \\
\hline & $15.2 \times 15.2$ & 13.9 & 13.7 & 12.1 & 13.2 \\
\hline & $15.2 \times 22.9$ & 13.4 & 12.7 & 12.4 & 12.8 \\
\hline & Whole leaf & 13.8 & 12.8 & 12.6 & 13.1 \\
\hline & Mean $^{a}$ & $13.6 \mathrm{a}$ & $13.0 \mathrm{~b}$ & $12.4 \mathrm{c}$ & 13.0 \\
\hline \multirow[t]{5}{*}{ \%Alkaloids } & $15.2 \times 7.6$ & 1.16 & 1.16 & 1.20 & $1.17 \mathrm{a}$ \\
\hline & $15.2 \times 15.2$ & 1.31 & 1.24 & 1.27 & $1.27 \mathrm{~b}$ \\
\hline & $15.2 \times 22.9$ & 1.36 & 1.35 & 1.43 & $1.38 \mathrm{c}$ \\
\hline & Whole leaf & 1.40 & 1.41 & 1.35 & $1.39 \mathrm{c}$ \\
\hline & Mean $^{a}$ & 1.31 & 1.29 & 1.31 & 1.30 \\
\hline
\end{tabular}

${ }^{a}$ Within leaf size or packing density for a given component, average values with the same letters $(a, b, c)$ were not significantly different according to an $F$-protected LSD test at $P=0.05$.

airflow effects due to strip orientation. These data indicate that tobacco placed in curing barns with horizontal mode orientation would receive considerably less airflow through the containers during curing than tobacco placed with vertical orientation. This was found to be the case, and examination of tobacco after curing showed complete drying for vertically oriented tobacco, but considerable incompletely dried tobacco and swelled stems in horizontally oriented tobacco. For the second cure, the packing density for the horizontal mode curing was reduced to 194 $\mathrm{kg} / \mathrm{m}^{3}$ and additional support rods added. While data indicated an increased airflow for a given pressure gradient, airflow was still inadequate to cure the tobacco completely within a reasonable curing schedule and a considerable amount of uncured tobacco was discarded. Further attempts were made in cures 3 and 4 to successfully cure tobacco in the horizontal mode; however, major problems were still observed. Because of these problems, chemical analyses and price evaluations are not reported for horizontal-mode tobaccos.

\section{Energy use}

Since the three barns for the major tests covered a wide range of green input weight for the three densities, it was of interest to note the effect of loading density on energy use per unit input weight. Table 4 shows values of total energy use for each barn for cures 1 through 4 . Increasing packing density from 194 to $243 \mathrm{~kg} / \mathrm{m}^{3}$ (25\% increase) resulted in about $14 \%$ reduction in specific energy use. A $50 \%$ increase in packing density to $292 \mathrm{~kg} / \mathrm{m}^{3}$ gave about $22 \%$ reduction in specific energy use.

\section{DISCUSSION}

Adverse weather conditions, with two hurricanes and excess rainfall during 1996, probably contributed to high 
Table 3. NCSU price index summary ${ }^{\mathrm{a}}$ for cured cut-strip and whole leaf tobacco, cures 1 through 4 (values are shown in US\$/kg)

\begin{tabular}{|c|c|c|c|c|c|}
\hline \multirow[b]{2}{*}{ Cure } & \multirow{2}{*}{$\begin{array}{l}\text { Leaf size } \\
(\mathrm{cm} \times \mathrm{cm})\end{array}$} & \multicolumn{3}{|c|}{ Packing density $\left(\mathrm{kg} / \mathrm{m}^{3}\right)$} & \multirow[b]{2}{*}{ Mean } \\
\hline & & 194 & 243 & 292 & \\
\hline \multirow[t]{4}{*}{1} & $15.2 \times 7.6 \mathrm{~cm}$ & 3.74 & 3.76 & 3.74 & 3.75 \\
\hline & $15.2 \times 15.2 \mathrm{~cm}$ & 3.76 & 3.76 & 3.76 & 3.76 \\
\hline & $15.2 \times 22.9 \mathrm{~cm}$ & 3.76 & 3.74 & 3.76 & 3.75 \\
\hline & Whole leaf & 3.76 & 3.76 & 3.76 & 3.76 \\
\hline \multirow[t]{4}{*}{2} & $15.2 \times 7.6 \mathrm{~cm}$ & 3.87 & 3.87 & 3.87 & 3.87 \\
\hline & $15.2 \times 15.2 \mathrm{~cm}$ & 3.87 & 3.87 & 3.87 & 3.87 \\
\hline & $15.2 \times 22.9 \mathrm{~cm}$ & 3.92 & 3.87 & 3.87 & 3.89 \\
\hline & Whole leaf & 3.87 & 3.87 & 3.87 & 3.87 \\
\hline \multirow[t]{4}{*}{3} & $15.2 \times 7.6 \mathrm{~cm}$ & 3.87 & 3.87 & 3.87 & 3.87 \\
\hline & $15.2 \times 15.2 \mathrm{~cm}$ & 3.87 & 3.87 & 3.87 & 3.87 \\
\hline & $15.2 \times 22.9 \mathrm{~cm}$ & 3.87 & 3.87 & 3.87 & 3.87 \\
\hline & Whole leaf & 3.87 & 3.87 & 3.87 & 3.87 \\
\hline \multirow[t]{4}{*}{4} & $15.2 \times 7.6 \mathrm{~cm}$ & 3.96 & 3.96 & 3.96 & 3.96 \\
\hline & $15.2 \times 15.2 \mathrm{~cm}$ & 3.96 & 3.96 & 3.96 & 3.96 \\
\hline & $15.2 \times 22.9 \mathrm{~cm}$ & 3.96 & 3.96 & 3.96 & 3.96 \\
\hline & Whole leaf & 3.96 & 3.96 & 3.96 & 3.96 \\
\hline \multirow[t]{5}{*}{ Average } & $15.2 \times 7.6 \mathrm{~cm}$ & 3.86 & 3.87 & 3.86 & 3.86 \\
\hline & $15.2 \times 15.2 \mathrm{~cm}$ & 3.87 & 3.87 & 3.87 & 3.87 \\
\hline & $15.2 \times 22.9 \mathrm{~cm}$ & 3.88 & 3.86 & 3.87 & 3.87 \\
\hline & Whole leaf & 3.87 & 3.87 & 3.87 & 3.87 \\
\hline & Overall mean & 3.87 & 3.87 & 3.87 & 3.87 \\
\hline
\end{tabular}

aprice index for flue-cured tobacco based on average prices paid for various grades per 100 pounds of untied tobacco for 1995 and 1996 for Types 11, 12, 13 and 14 combined through September 6, 1996.

starch contents and lower sugar and alkaloid levels for both intact and cut-strip tobaccos. While harvested tobacco appeared "ripe", it is suspected that the leaf did not develop fully in the field, leading to cured leaf having an "immaturity factor".

The trend for higher cured leaf starch contents for smaller strip sizes suggests the possibility of more rapid drying rates for the cut-strip material during the yellowing phase, which may have led to reduced starch hydrolysis. If this hypothesis is correct, this can be addressed by modifying the drying potential during yellowing. Another possible factor may be greater bruising for the smaller cut-strip sizes. In addition to having more cut edge per unit area, the smaller cut-strips were subjected to a higher impact velocity during the cross cutting operation. The smaller cut strips $(15.2 \times 7.6 \mathrm{~cm})$ had $79 \%$ more cut edge/area than the larger strips $(15.2 \times 22.9 \mathrm{~cm})$. In addition, impact velocity of the cross-cutter blades was $200 \%$ higher for the smaller cut strips than for the larger strips. It is known that bruising can significantly suppress starch degradation during curing $(8,10)$. Hence, further study is indicated to determine the effect of various machine design parameters on possible bruising and starch concentrations of cured leaf.

Results for sugars suggest little difference in respiratory activity of cut-strip $v s$. intact leaf during the curing process for cut-strip sizes of $15.2 \times 7.6 \mathrm{~cm}$ and above.

Slightly higher alkaloid levels with larger strip size, while
Table 4. Energy use ( $\mathrm{kWh} / \mathrm{kg}$ green tobacco) in relation to packing density for cut-strip curing tests, cures 1 through 4

\begin{tabular}{l|lll|l}
\hline \multirow{2}{*}{ Cure } & \multicolumn{3}{|c|}{ Packing density $\left(\mathrm{kg} / \mathrm{m}^{3}\right)$} & \\
\cline { 2 - 4 } & 194 & 243 & 292 & Mean $^{\mathrm{a}}$ \\
\hline 1 & 2.47 & 2.26 & 1.89 & $2.21 \mathrm{a}$ \\
2 & 1.57 & 1.29 & 1.29 & $1.38 \mathrm{~b}$ \\
3 & 1.50 & 1.22 & 1.07 & $1.26 \mathrm{~b}$ \\
4 & 1.41 & 1.19 & 1.15 & $1.25 \mathrm{~b}$ \\
Mean $^{\mathbf{a}}$ & $\mathbf{1 . 7 4} \mathbf{~ a}$ & $\mathbf{1 . 4 9} \mathbf{~ b}$ & $\mathbf{1 . 3 5} \mathbf{~ b}$ & $\mathbf{1 . 5 3}$ \\
\hline
\end{tabular}

aWithin cure or density, average values with the same letter are not significantly different at the 0.05 level of $F$ (Duncan's multiple range) test.

significant, are difficult to explain inasmuch as alkaloids generally change little during curing.

The fact that packing density had little apparent effect on chemistry (except for a slight effect on reducing sugars) and government grade suggests that the curing capacity of existing farmer equipment could be increased as much as $50 \%$ above current levels. This would significantly reduce farmers curing costs and capital investment for barns. Not only does the data indicate facility cost reductions per $\mathrm{kg}$ cured leaf, but also significant energy savings, probably due to reduced heat loss per unit of cured material. Results of subjective grading suggest also that cut-strip tobacco compares favorably with intact leaf when cured under the same conditions.

Vertical orientation of leaves or cut-strip tobacco appears to be the optimum orientation for vertical air movement. With our present knowledge and currently available curing systems, rotation of curing containers after filling to position leaves or strips vertical seems necessary to achieve efficient curing of high quality leaf.

Acknowledgment: The authors wish to express appreciation to the following companies and Foundation for financial support provided for this research: Brown \& Williamson Tobacco Corporation, Lorillard Tobacco Company, Philip Morris USA, R. J. Reynolds Tobacco Company, and The North Carolina Tobacco Foundation, Inc.

\section{REFERENCES}

1. Johnson, W.H, W.H. Henson, Jr., F.J. Hassler, and R.W. Watkins: Bulk curing of bright-leaf tobacco; Agric. Engr. 41 (1960) 511-517.

2. Johnson, W.H., F.J. Hassler, and W.H. Henson, Jr.: Some determinations pertinent to removal of midrib from bright-leaf tobacco during curing operations; Tob. Sci. 1 (1957) 164-168.

3. Johnson, W.H.: Modular handling and curing studies - 1975; in: An annual report of accomplishments in tobacco research in North Carolina, April 1 through March 31, 1976, Departmental report of Biological and Agricultural Engineering, N.C. State University, Raleigh, N.C., 1976. 
4. Johnson, W.H.: Tobacco processing system and method; U.S. Patent No. 3,885,376, 1975.

5. Johnson, W.H.: Tobacco handling and curing system and method; U.S. Patent No. 3,899,836, 1975.

6. Revels, J.E.: Investigation of cut-strip tobacco as a method to increase handling and curing efficiency of flue-cured tobacco; M.S. thesis, Department of Biological and Agricultural Engineering, N.C. State University, Raleigh, N.C., 1997.

7. Suggs, C.W., H.B. Peel, and T.R. Seaboch: Bulk density and drying effect on airflow through flue-cured tobacco leaves; Tob. Sci. 33 (1989) 86-90.

8. Comber, R.: The effect of bruising on starch degradation in Virginia tobacco leaves; Beitr. Tabakforsch. 9 (1977) 53-57.

9. Johnson, W.H. and F.J. Hassler: Carbon dioxide liberation and carbohydrate accumulation during the yellowing phase of tobacco curing; Tob. Sci. 7 (1963) 85-92.

10. Johnson, W.H., F.J. Hassler, and W.H. Henson, Jr.: Effects of bruising on tobacco curability; Tob. Sci. 1 (1957) 177-179.

11. Anderson, D.S., Y. Abubakar, J.H. Young, and W.H. Johnson: Pressure vs. airflow characteristics through fresh intact and cut-strip tobacco; Trans. of the ASAE 41 (1998) No. 6, 1747-1753.
12. Suggs, C. W., L. L. Blalock, and H.B. Peel: Technical Note: Airflow through fresh tobacco leaf particles, Trans. of the ASAE 29 (1986) No. 4, 1156-1161.

13. Young, J.H., J.C. Tutor, E.P. Harris, and C. Lin: Microcomputer monitoring and control of bulk tobacco curing barns; in: Proceedings of sixth international conference on computers in agriculture, Cancun, Mexico, published by American Society of Agricultural Engineers, Saint Joseph, MI, 1996, pp. 237-245.

14. Chang, C.S. and W.H. Johnson: Packing density distribution of cut-strip tobacco in curing modules; Tob. Sci. 22 (1976) 19-23.

Address for correspondence

William H. Johnson

North Carolina State University

Department of Biological and Agricultural Engineering

Raleigh, North Carolina, U.S.A.

e-mail address is wiohnson@unity.ncsu.edu. 